\title{
A Fresh Approach: Ethnic Diversity On Campuses In America
}

\author{
Pamela E. Ray, University of the Incarnate Word, USA
}

\begin{abstract}
The Historical Black Colleges and Universities (HBCU) has defined its legacy. The HBCU developed campuses to prepare African-Americans for a variety of careers. They are considered to be specialized educational system within higher education. This system provided a way for many African-Americans to showcase their intellectual abilities. The HBCU's historical context and missions primarily focus on African-Americans (Roebuck \& Komanduri, 1993). As education for African-Americans changed, access to college became more inclusive. More HBCU's face adversity and diversity, with challenges brought on by a more diverse student population. This article describes how the HBCUs must look at ethnic diversity on campuses. Then begin the challenge of modifying traditional missions based on serving one type of ethnic student population.
\end{abstract}

Keywords: Diversity, multiculturalism, institutional transformation, chief diversity officer

\section{INTRODUCTION}

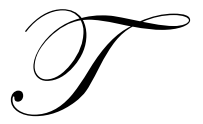

he Higher Education Act of 1965 defines designated HBCU as a historically black college or university established before 1964 with the primary mission to educate "black" Americans (Department of Education, 2008). Wars and legal cases provided the historical background for the development of the HBCU. HBCU schools prepared African-American students by offering leadership roles in areas of agriculture, mechanics, law, medicine and politics. A historical resilience confirmed how a specialized higher education system evolved over time, especially during times of scarce economic resources, accessibility and capacity to serve African-American students ${ }^{(T h e l i n, 2004)}$. History described a time when African-Americans struggled through society. These struggles were due to inequality, racism and restrictions to advancement. Education was the historical platform used to remove restrictions and provide equality of life. During slavery, African-Americans established an educational system. Hall ${ }^{(1973)}$ stated that "slaves were granted apprenticeships to learn specific skills from white skilled workers" ${ }^{(p .2)}$.

Booker T. Washington and W.E.B. Dubois were influential in the establishment of HBCUs. Washington ${ }^{(1903)}$ wrote, "slaves learned skills on plantations as the first structured educational system" (p.5). Along with farming, some skills described by Washington included brick masonry, sewing, housekeeping, and blacksmith. These basic skills were essential to survival, and allowed the plantation to serve as the first infrastructure of an educational system. In addition, further advancement of African-Americans led to the need for additional educational training in math, science and religion for pursuing careers as teachers, doctors, minister or lawyers (Provenzo, 2002). In an essay, W.E.B. DuBois ${ }^{(1903)}$ provided a theory about the HBCU's role of education and leadership for African-Americans. He described education as a system that African-Americans can use to prepare "exceptional men" to go forth and educate others ${ }^{\text {(Talented Tenth, p.33). }}$

The Civil War played a role in the government prompting the advancement of African-Americans. The government began the transition to a more formalized educational system that allowed "blacks" to be educated on property or land under the First and Second Morill Acts. The First Morill Act of 1852 allowed for land to be donated to colleges for agriculture and mechanics (Higher Education Resource Hub, 2008). The Second Morill Act of 1890 allowed for further expansion of colleges, and prohibited the practices of inequality, such as admitting student based on race ${ }^{\text {(US Department of Agriculture, 2009). }}$ 
Historical Supreme Court cases also had an impact in the development of the HBCUs. The landmark Plessy v. Ferguson ${ }^{(1896)}$ established "separate but equal" in public education (Kaplin and Lee, 2007). Plessy paid for a firstclass seat on a train and was asked if he was "colored" to determine if he needed to give up his seat on the train. Plessey felt this was not fair when he paid the same price as "white" travelers. This landmark case prompted society to continue to look at equality through the lens of justice. The HBCU educational system began to take shape and offered methods to ensure equal opportunity. Another landmark legal case includes Brown v. Board of Education (1954). The Civil Rights Act of 1964 and the Higher Education Act of 1965 also marked a period of moving from segregation to desegregation.

This article is based on a historical journey of HBCU's. It is divided into three parts. The first part provides a historical, methodical and systematic description of the HBCU. The second part defines types of diversity on the HBCU campus, and changing student demographics. Finally, the third part provides an analysis of research and literature about best practices to serving diverse student populations of HBCUs.

\section{HISTORICAL JOURNEY OF THE HBCU}

\section{Methodical and Systematic}

The educational methods of HBCUs were built on the foundation of skilled trade workers. The first approach started during slavery. Slaves gained skills working on plantations, and then granted apprenticeships ${ }^{\text {(Hall, }}$ 1973). The trades of sewing, brick masonry, blacksmith and farming were an investment to the economy. After apprenticeships, skilled workers attended training at Northern Schools. Donations and philanthropy started the movement toward an industrial segregated school system. Industrial schools were formed in the North but many failed. They were unsuccessful due to the opposition of African-Americans becoming self-sufficient. Other obstacles included limited funding and poor structural condition.

Training manuals were developed to teach certain techniques. African-American skilled trade workers were learned through the methods of apprenticeship, training manuals and job experience. Historians described this method of industrialized training as a combined effort of Southern and Northern industrialists. Wagoner (1981) described the efforts to remove the stigma of slavery by "Southern industrialists and Northern philanthropists" as means to a "workable scheme of social organization" (p. 459). This industrialized method helped develop numerous colleges and universities with missions in educating African-Americans. These colleges and universities were developed based on a method the industrial education. Governmental practices, politics and policies continued to play an intricate role in the development of comprehensive programs based on industrial skills. The Higher Education Act of 1965 gave rise to the HBCU designation. The campuses were designated as public or private.

There are two HBCU institutions that paved the way in using the industrialized method to train AfricanAmericans in higher education. Cheney University was the first established HBCU in North America. It started as the Philadelphia Institute for Colored Youth, and land was purchased to teach "mechanics and agriculture" (Hall, 1973). Hampton Institute and Tuskegee University were recognized for industrial education. They served as models for starting "Industrial Art or Applied Science" departments (Provenzo, 2002). Amendments to the Higher Education Act (1966) allowed for additional industrial arts courses, and considered "critical subjects" to improve instructions.

As a growing debate took place about trade skills versus professional skills, so did the debate of HBCUs. These debates were based on liberal versus "practical education" (Thelin 2002). Other HBCU colleges started to offer courses in philosophy, English, sociology and religion. These courses were geared toward the graduate planning to work as a teacher, minister, doctor or lawyer. The debates were viable to a culture trying to survive through an era of inequality. The logic behind historical debates proved a mode of strength to empower the HBCU toward an essential legacy in higher education. 


\section{DEFINING DIVERSITY}

\section{Types of Diversity}

The HBCU historical commitment to educate one type of population came about by being excluded from higher education. The resistance to desegregation in higher education has disappeared. Because of the great push toward diversity, clear and concise definitions are being established. Ranley ${ }^{(2009)}$ used the Oxford dictionary definition of diversity as "the condition or quality of being diverse, different, or varied; difference, unlikeness - an example, the human race" (p.1). As students are faced with difficult and diverse demands from society, campuses are using research to examine "perceptions and attitudes" of particular groups as they relate to racial/ethnic diversity (Hurtado, Milem, Pedersen and Allen, 1999). Many campuses are dealing with racial/ethnic diversity on campuses through institutional transformation. Hurtado, Milem, Pedersen and Allen ${ }^{(1999, \text { p. } 20)}$ describe institutional transformation as having a multicultural approach that bring about change in students social and academic life on campus.

\section{DIVERSITY IN STUDENT POPULATIONS}

\section{Diverse Student Trends}

To date, there are 105 HBCUs [see Appendix ] 2-and 4-year colleges/universities across the United States (Department of Education, 2008). The majority are located in Alabama and North Carolina. The National Center for Educational Research ${ }^{(2001)}$ reported student enrollment as the following:

1. Over 200,000 students attend a HBCU.

2. $90 \%$ of HBCU students attend 4-year institutions while $10 \%$ attend 2-year colleges; and the rate of women is higher than men.

3. $\quad$ More students attend a 4-year institution compared to 2-year colleges.

4. Student demographics found that in $200182 \%$ of students were African-American compared to 1976 in which $85 \%$ of the student population was African-American.

Admissions for African-Americans have been opened at other traditional colleges. Sims ${ }^{(1994)}$ cited a 1971 report by the Carnegie Commission on Higher Education that by the 21 st Century enrollment must increase to about 2 million at HBCU's to be similar to other institutions. The National Center for Educational Statistics ${ }^{(2001)}$ reported that $10 \%$ of HBCU students attended 2-year institutions, and were more likely to attend public versus private, nonprofit institutions. Current data has led to further debate about the HBCU existence and diversity. Experts have asked critical questions about the HBCU ability to redefine its mission. Two questions for consideration are: 1) Is there a need for the HBCU? 2) Can the HBCU be changed or advanced into a diverse culture?

\section{DISCUSSION}

The Chronicle of Higher Education ${ }^{\text {(Shireman, } 2003)}$ suggested ways for colleges to assess campus history and data as they relate to diversity issues. The study suggested ten key questions for college officials:

1. How do we define diversity?

2. Why do we have this particular array of students

3. Who gets financial aid?

4. How successful are our students?

5. What multicultural education are students receiving?

6. What does it feel like as a student to be here?

7. Who are faculty leaders?

8. What are our relationships with nearby communities?

9. Who is thinking about these issues on our campus?

10. What do we want to change, and how will we know that we have changed it? 
This article provides insight on administration taking steps in visionary change. The scope leads to an overarching approach while examining the $\mathrm{HBCU}$ institutional missions.

In an interview with The Chronicle of Higher Education ${ }^{\text {(Roach, 2009) }}$ Mary Broad, President of the American Council on Education, she states,

"I don't think you ever have to modify your historical mission. But the understanding of diversity that exists in HBCUs can logically be extended to other students of color, to rapidly growing Hispanic population, to Asians. There is an understanding and a sensitivity at HBCUs that you might not see at other institutions and the richness of the experience in the classroom when you have students from many different races and backgrounds is what helps to enhance the learning" ${ }^{(p .12)}$.

This statement discusses the possibilities for HBCUs to modify their current missions to represent culturally diverse students.

Another approach discussed is the administrative position, chief diversity officer. Some criticize this position as a way of removing responsibility for ensuring diversity from other top administrators (i.e. President, Provosts). Williams and Golden ${ }^{(2008)}$ explain that research on this role has found two important characteristics that lead to change using collaborative and integrative leadership. Key concepts from this article can also be applied at other college campuses. At an HBCU this may also help increase the number of underrepresented groups on campus.

A study by Ioannou ${ }^{(2009)}$ provides research assessing diversity through a survey that found campuses can be successful based on "recruitment, retaining, marketing and communication diversity, provide education for diversity and climate for diversity" ${ }^{(p .17)}$. This survey was conducted at a large non-HBCU campus; however, it can apply at any campus that will allow participation by faculty, staff and students. Dwyer ${ }^{(2006)}$ reviews how HBCU campuses are dealing with diversification. His research data shows a growing rate of white and other minority students attending HBCUs which create more diversity. Dwyer further discusses the HBCU multicultural literature, calling it "scarce, disparate and unconnected" (p. 47). This examination of various literature continues to raise the question about diversity at HBCU campuses. More concepts are derived, but there still remains the need for a connection to global aspect of diversity in higher education.

Much of the literature about diversity at today's HBCUs is very limited. Research seems to focus on racial/ethnic diversity, compared to other issues defined by multiculturalism. Dwyer ${ }^{(2006)}$ notes limited literature in higher education about multiculturalism on HBCU campuses. The research recognizes that literature does not focus on the existence of "multiculturalism on campus, or how multicultural education" at primary and secondary levels prepares students for HBCUs ${ }^{(p .41)}$. There appears to be a need for current research about multiculturalism in higher education, especially at specialized campuses like HBCUs.

As HBCUs deal with changes in student trends, they must face the challenge of looking at diversity beyond race and ethnicity. It is suggested that diversity be explored based on issues such as gender, religious practices and students that considered as English as a second language learners (ESLL). Campus administrators need to explore the impact of diversity at all levels on campus personnel, and students. Davis and Swartz ${ }^{(2008)}$ state, “...the approach to coping with diversity issues is through deliberate, conscious, and consistent application of carefully thought-out policies and procedures" (p.11). Therefore, it is highly recommended more research examine campus policies and procedures to ensure diversity.

\section{SUMMARY}

\section{Conclusion}

As student demographics are changing on HBCU campuses, an increase for diversification is warranted. This appears to be broad campus research rather than individual students or faculty. HBCU education is becoming more diversified, and research is needed with other minority students. Sims ${ }^{(1994)}$ described the HBCU mission as 
bringing students together in non-threatening environments for tradition, pride, and leadership development. Two areas can contribute to further research: 1) additional research based on Sims viewpoint about the HBCUs mission, and 2) using transformation theory to study institutional transformation as it relates to multiculturalism at HBCUs.

\section{AUTHOR INFORMATION}

Pamela E. Ray is Assistant Professor/Chairperson of the Early Childhood and Family Studies Department at St. Philip's College. Pam earned a BA in Psychology/Special Education, Master's of Human Relations, and completed post-graduate studies in early childhood education from New Mexico State and Cameron Universities. Currently, she is a doctoral student at University of the Incarnate Word. Ms Ray was awarded NISOD Excellence in Teaching, San Antonio Black Achievement Award and Business Journal, 40 Under 40 Rising Stars. Pam is a member of Jacob's Chapel United Methodist Church and Alpha Kappa Alpha Sorority, Incorporated. She is married, and has one son.

\section{REFERENCES}

1. Davis, W. \& Swartz, C. (2008). Twelve Commandments of Human Relations for the Diverse Academic Environment of College and Universities. Contemporary Issues In Educational Research, 1, 2 , 9-21

2. Dwyer, B. (2006). Framing the Effect of Multiculturalism on Diversity Outcomes among Students at Historically Black Colleges and Universities. Educational Foundations, Winter-Spring.

3. Hall, C. (1973). Black Vocational Technical and Industrial Arts Education: Development and History. Chicago, ILL: American Technical Society

4. Higher Education Resource Hub (2009). An Explanation of the First Morril Act, Land Grants: First Morrill Act. Retrieved on June 3, 2009 from http:www.higher-ed.org/resources/mirril1.htm

5. Hurtado, S., Milem, J., Pedersen, A. \& Allen, W. (1999). Enacting Diverse Learning Environments: Improving the Climate for Racial/Ethnic Diversity in Higher Education. ASHE-Eric Higher Education Report Volume 26, No. 8 Washington, D.C.: The George Washington University, Graduate School of Education and Human Development.

6. Ioannou, A. (2008). Development and Initial Validation of a Satisfaction Scale on Diversity. Retried on July 11, 2009 from ERIC database, presented at 2008 meeting of American Educational Research Association, NY.

7. Kaplin, William A. \& Lee, Barbara A. (2007). The Law of Higher Education (4 ${ }^{\text {th }}$ ed.) (Student Version). San Francisco, California: John Wiley \& Sons, Inc.

8. National Center for Educational Statistics (2001). Historically Black Colleges and Universities, 1976 to 2001. Retrieved on June 17, 2009 from http://nces.ed.gov/pubs2004/hbcu/Section2.asp

9. Provenzo, E. (2002). Introduction. DuBois on Education (pp. 1-17). Lanham MD: Rowman \& Littlefield Publishers, Inc.

10. Ranley, E. (2009). Diversity. Retrieved from July 12, 2009 from http://www.deliriumjournal.org/dd.html

11. Roach, S. (2003). The New Era of Diversity. The Chronicle of Higher Education, 25, 25. p. 11-13. Retrieved on July 11, 2009 from Academic Search Complete http://search.ebsocohost.com/login.aspx?direct=true\&db=a9h\&AN=36322135\&site=ehost-live" $>$ The New Era of Diversity. $\langle/ \mathrm{A}>$

12. Robebuck, J. \& Komanduri, M. (1993). Historically Black Colleges and Universities: Their Place in American Higher Education. Praeger Publishers, Westport, CT

13. Shireman, R. (2003). 10 Questions College Officials Should Ask About Diversity. The Chronicle of Higher Education, 49, 49. p. 1-4. Retrieved on July 11, 2009 from http://chronicle.com/weekly/v49/i49/49b01001.htm

14. Sims, S. (1994). Definitions, Histories and Issues. In Diversifying Historically Black Colleges and Universities. (pp. 1-19). Westport, Ct: Greenwood Press

15. Thelin, R. J. (2004). Diversity and Adversity, Resilience in American Higher Education, 1860 to 1890. In A History of American Higher Education (pp. 74-109). Baltimore, MD: The John Hopkins University Press 
16. “The Talented Tenth" from The Negro Problem: A Series of Articles by Representative Negroes of Today (New York: James Pott \& Co, 1903), pp. 33-73. Reprinted by Arno Press in 1969. In ASHE Reader on The History of Higher Education, $2^{\text {nd }}$ edition, Pearson Custom Publishing, Boston, MA

17. US Department of Agriculture-Cooperative State Research, Education and Extension Services. Second Morrill Act of 1890. Retrieved on June 11, 2009 from http://www.csrees.usda.gov/about/offices/legis/secondmorrill.html

18. US Department of Education. The Higher Education Act of 1965. Retrieved on June 4, 2009 from http://www.ed.gov

19. US Department of Education. The Higher Education Act of 1966-Amendments. Retrieved on June 4, 2009 from http://www.ed.gov

20. US Supreme Court (1896). Plessy v. Ferguson, 163 US 537. Retrieved May 22, 2009, from http://supreme.justia.com/us/163/537/index.html

21. Wagnoer, J. (1981). The American Compromise: Charles W. Eliot, Black Education and the New South. Reprinted by Simon \& Schuster Macmillan in 1981. In ASHE Reader on The History of Higher Education, $2^{\text {nd }}$ edition, Pearson Custom Publishing, Boston, MA

22. Williams, D. \& Golden, K. (2008). The Complex Mandate of a Chief Diversity Officer. Retrieved on July 11, 2009 from http://chronicle.com/weekly/v55/i05/05b04401.htm 


\section{APPENDIX}

\begin{tabular}{|c|c|}
\hline \multicolumn{2}{|c|}{ Historically Black Colleges and Universities } \\
\hline Alabama & Arkansas \\
\hline Four-Year Public & Four-Year Public \\
\hline Alabama A\&M University & University of Arkansas at Pine Bluff \\
\hline Four-Year Private & Four-Year Private \\
\hline Concordia College Selma & Arkansas Baptist College \\
\hline Miles College & Philander Smith College \\
\hline Oakwood University & \\
\hline Selma University & \\
\hline Stillman College & \\
\hline Talladega College & \\
\hline Tuskegee University & \\
\hline Two-Year Public & \\
\hline Bishop State Community College & \\
\hline Shelton State Community College, C.A. & \\
\hline Gadsden State Community College, Vall & \\
\hline J.F. Drake State Technical College & \\
\hline Lawson State Community College & \\
\hline Trenholm State Technical College & \\
\hline Delaware & Florida \\
\hline Four-Year Public & Four-Year Public \\
\hline Delaware State University & Florida A\&M University \\
\hline District of Columbia & Four-Year Private \\
\hline Four-Year Public & Bethune-Cookman College \\
\hline University of the District of Columbia & Edward Waters College \\
\hline Four-Year Private & Florida Memorial University \\
\hline Howard University & \\
\hline Georgia & Kentucky \\
\hline Four-Year Public & Four-Year Public \\
\hline Albany State University & Kentucky State University \\
\hline Fort Valley State University & \\
\hline Savannah State University & \\
\hline Four-Year Private & \\
\hline Clark Atlanta University & \\
\hline Interdenominational Theological Center & \\
\hline Morehouse College & \\
\hline Morehouse School of Medicine & \\
\hline Morris Brown College & \\
\hline Paine College & \\
\hline Spelman College & \\
\hline
\end{tabular}




\begin{tabular}{|c|c|}
\hline \multicolumn{2}{|c|}{ Historically Black Colleges and Universities (cont'd) } \\
\hline Louisiana & Maryland \\
\hline Four-Year Public & Four-Year Public \\
\hline Grambling State University & Bowie State University \\
\hline Southern University A\&M College & Coppin State College \\
\hline Southern University at New Orleans & Morgan State University \\
\hline Four-Year Private & University of Maryland Eastern Shore \\
\hline Dillard University of Louisiana & \\
\hline Xavier University & \\
\hline Two-Year Public & \\
\hline Southern University at Shreveport & \\
\hline Michigan & Mississippi \\
\hline Two-Year Private & Four-Year Public \\
\hline Lewis College of Business & Alcorn State University \\
\hline & Jackson State University \\
\hline & Mississippi Valley State University \\
\hline & Four-Year Private \\
\hline & Rust College \\
\hline & Tougaloo College \\
\hline & Two-Year Public \\
\hline & Coahoma Community College \\
\hline & Hinds Community College, Utica \\
\hline Missouri & North Carolina \\
\hline Four-Year Public & Four-Year Public \\
\hline Harris-Stowe State University & Elizabeth City State University \\
\hline Lincoln University & Fayetteville State University \\
\hline & North Caroline A\&T University \\
\hline & North Carolina Central University \\
\hline & Winston-Salem University \\
\hline & Four-Year Private \\
\hline & Barber-Scotia College \\
\hline & Bennett College \\
\hline & Johnson C. Smith University \\
\hline & Livingston College \\
\hline & Shaw University \\
\hline & St. Augustine's College \\
\hline Ohio & Oklahoma \\
\hline Four-Year Public & Four-Year Public \\
\hline Central State University & Langston University \\
\hline Four-Year Private & \\
\hline Wilberforce University & \\
\hline Pennsylvania & \\
\hline Four-Year Public & \\
\hline Cheyney University of Pennsylvania & \\
\hline Lincoln University & \\
\hline
\end{tabular}




\begin{tabular}{|ll|}
\hline \multicolumn{2}{|c|}{ Historically Black Colleges and Universities (cont'd) } \\
South Carolina & Tennessee \\
Four-Year Public & Four-Year Public \\
South Carolina State University & Tennessee State University \\
Four-Year Private & Four-Year Private \\
Allen University & Fisk University \\
Benedict College & Knoxville College \\
Claflin University & Lane College \\
Morris College & Lemoyne-Owen College \\
Voorhees College & Meharry Medical College \\
Two-Year Public & \\
Denmark Technical College & \\
Two-Year Private & \\
Clinton Junior College & \\
& \\
Texas & \\
Four-Year Public & \\
Prairie View A\&M University & \\
Texas Southern University & Virginia \\
Four-Year Private & Four-Year Public \\
Huston-Tillotson University & Norfolk State University \\
Jarvis Christian College & Virginia State University \\
Paul Quinn College & Four-Year Private \\
Southwestern Christian College & Hampton University \\
Texas College & Saint Paul's College \\
Wiley College & Virginia Union University \\
Two-Year Public & Virginia University of Lynchburg \\
St. Philip's College & \\
& \\
West Virginia U.S. & \\
Four-Year Public & \\
Bluefield State College & \\
West Virginia State University & \\
Source: US Department of Education (2008). White House Initiative on Historically Black Colleges and \\
Universities". Retrieved on June 13, 2009 from http://www.ed.gov/about/inits/list/whhbcu/edlite-index.html. \\
& \\
& \\
& \\
& \\
& \\
& \\
& \\
& \\
& \\
&
\end{tabular}


NOTES 